\title{
A1. A Rare Cause of Dyspnea: A Giant Vocal Polyp
}

\section{Dispnenin Nadir bir Nedeni: Dev Vokal Polip}

Dear Editor,

Vocal polyps (VPs) are usually one-sided lesions which occur with increased subepithelial edema. Chronic laryngeal irritants may cause VPs. It ordinarily develops on the anterior and middle third intersection of the free edge of the vocal folds, as this area is the most common region exposed to the chronic irritants (1). VPs can be edematous, fibrous, and hyalen pathologically. The most common symptom is hoarseness. Diplophonia and tickling on the throat are also possible symptoms (1). They rarely grow enough to cause dyspnea. When VPs are in the early stage and non-organized, voice therapy and avoidance of local irritants can be used in treatment. In case of resistance to these therapies, surgery should be applied (2).

A 43-year-old man was admitted to our clinic with the complaints of hoarseness for three years, tickling on his throat and emerging respiratory distress. He was a smoker for 30 years and had gastroesophageal reflux symptoms. He was free of hemoptysis, weight loss, and dysphagia. He had no another chronic diseases. His otolaryngological examination findings were normal except the larynx. There was a huge VP on his left vocal fold (Figure (A-B). It was moving during the respiration. There was no dysplastic change. His lung and heart sounds, chest $X$-ray, and electrocardiography results were normal. The patient was operated under general anesthesia and the VP removed by the cold knife microscopically. No dysplastic change was observed. It included stratified squamous epithelium and edematous stroma microscopically (Figure 1C). He was discharged with recommendation of smoking cessation, anti-reflux medication, and sound rest. During the postoperative examination, his symptoms relieved and larynx was normal (Figure 1D).
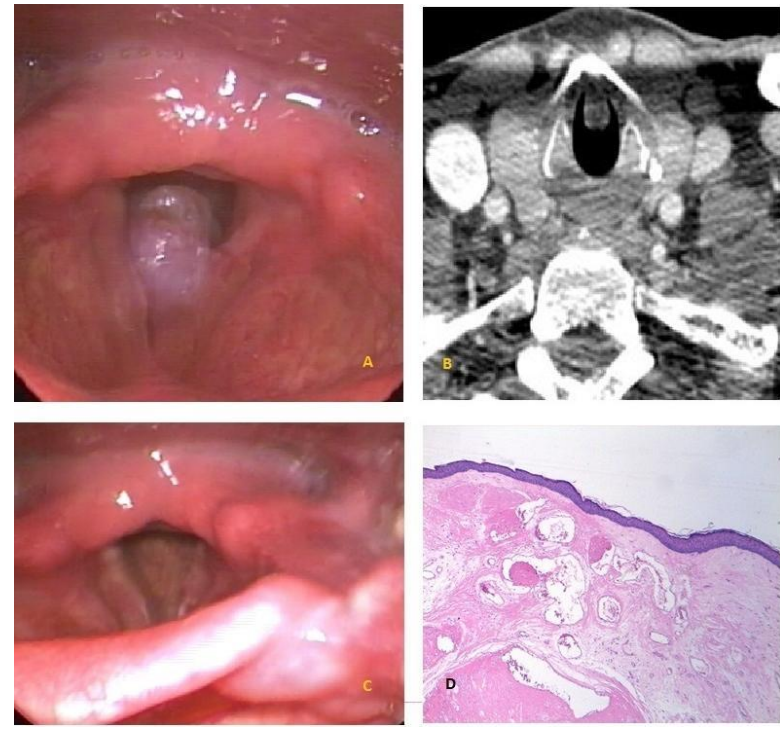

Figure 1: Preoperative endoscopic image of a giant vocal polyp, laryngeal airway is narrowed (A). Computed tomography of a vocal polyp (B), postoperative endoscopic image (C), microscopic image of a vocal polyp, there are stratified squamous epithelium on and edematous stroma with vessels in different sizes (D) (H\&E, X40)

Vocal polyps, one of the most common benign mucosal lesions of larynx, usually affect men (3). During its development, capillary rupture of the vessel occurs firstly and the blood fills in the Reinke space. Then, proliferations of fibroblast, vascular and stromal hyalinization occur. Most of VPs are small and develop from free-edge of the true vocal folds. Common symptoms include hoarseness, voice fatigue, and diplophonia. They may sometimes reach a huge size, causing choking, stridor, and dyspnea (1). Dyspnea can be defined as breathing with an uncomfortable sense. It is usually seen in patients who have pulmonary and cardiac diseases. The most common reasons are asthma, chronic obstructive pulmonary disease, neuromuscular diseases, and pulmonary embolism (4). Laryngeal obstructions can also be a reason of respiratory distress. However, it is unlikely to develop a VP-induced dyspnea. Furthermore, VPs are ordinarily on the anterior part 
of the vocal folds. Therefore, respiratory distress is not expected in these patients. Cardiopulmonary diseases and sudden death due to a VP have been reported in the literature (5).

A giant VP is a rare cause of dyspnea. In the patients who have dyspnea without a cardiopulmonary disease, laryngeal obstruction should be considered. These polyps may sometimes respond to the voice therapy; however, for a VP which causes dyspnea, treatment option should be surgery.

\section{Kerem Kökoğlu', Irfan Kara', Şerife Seçil Karabulut ${ }^{2}$, Sedat Çağlı' ${ }^{1}$ İmdat Yüce'}

\footnotetext{
'Department of Otolaryngology - Head And Neck Surgery, Erciyes University, Kayseri, Turkey

${ }^{2}$ Department of Pathology, Erciyes University, Kayseri, Turkey

Correspondence (iletişim): Kerem Kökoğlu, Department of Otolaryngology - Head And Neck Surgery, Erciyes University, Kayseri, Turkey

e-mail:dr.kokoglu@gmail.com
}

\section{CONFLICTS OF INTEREST}

None declared.

\section{AUTHOR CONTRIBUTIONS}

Concept - K.K., I.K., S.S.K., S.Ç., I.Y.; Planning and Design - K.K., I.K., S.S.K., S.Ç., I.Y.; Supervision K.K., I.K., Ş.S.K., S.Ç., I.Y.; Funding - I.K., Ş.S.K.; Materials - K.K., I.K.; Data Collection and/or Processing - I.K., S.Ç.; Analysis and/or Interpretation -
K.K., I.K.; Literature Review - S.Ç., I.Y.; Writing K.K., I.K.; Critical Review - S.Ç., I.Y.

\section{YAZAR KATKILARI}

Fikir - K.K., I.K., S.S.K., S.Ç., I.Y.; Tasarım ve Dizayn - K.K., I.K., S..S.K., S.Ç., I.Y.; Denetleme - Z K.K., I.K., S.S.K., S.Ç., I.Y.; Kaynaklar - I.K., S.S.K.; Malzemeler - K.K., I.K.; Veri Toplama ve/veya İşleme - I.K., S.Ç.; Analiz ve/veya Yorum - K.K., I.K.; Literatür Taraması - S.Ç., İ.Y.; Yazıyı Yazan - K.K., I.K.; Eleştirel İnceleme - S.Ç., I.Y.

\section{REFERENCES:}

1. Karasu MF, Gundogdu R, Cagli S, Aydin M, Arli T, Aydemir $S$, et al. Comparison of effects on voice of diode laser and cold knife microlaryngology techniques for vocal fold polyps. J Voice 2014; 28:38792. [CrossRef]

2. Garrett CG, Francis DO. Is surgery necessary for all vocal fold polyps? Laryngoscope 2014; 124:363-4. [CrossRef]

3. Byeon HK, Kim JH, Kwon JH, Jo KH, Hong HJ, Choi HS. Clinical characteristics of vocal polyps with underlying sulcus vocalis. J Voice 2013; 27:632-5. [CrossRef]

4. Manning HL, Schwartzstein RM. Pathophysiology of dyspnea. N Engl J Med 1995; 333:1547-53. [CrossRef]

5. Rosell Ferrer MR, Aguilà Artal A, Vivancos Marín J, Bella MR, Saiz Arnaiz JM, Boada Estivill JI. Giant laryngeal polyps. Report of three cases and review of the literature. Acta Otorrinolaringol Esp 1997; 48:587-9. 